\title{
Productivity and Carbon Balance of Soybean-Corn Intercrops are affected by the Density of Corn
}

\author{
G. Giambastiani ${ }^{1}$ \\ ${ }^{1}$ Faculty of Agricultural Sciences, National University of Cordoba, Av.Valparaíso s/n $\mathrm{n}^{\mathrm{o}}$, Ciudad Universitaria, Cordoba, Argentina
}

\begin{abstract}
The area planted with soybean in Argentina has increased steadily in recent years along with the reduction of the area sown with cereals such as corn or sorghum. This affected negatively the soil quality, resulting in a negative carbon balance and decrease in organic matter content of the soil. The objective of this work was to evaluate the effect of corn density on grain yield, dry matter productivity and carbon balance of soybean - corn intercrops. The treatments were pure stand of soybean (PS), pure stand of corn (PC) and four intercrops varying in corn densities: 1, 2, 4 and 8 plants*m ${ }^{-2}$ (named SCI1, SCI2, SCI4 and SCI8, respectively). The experiments were conducted during two seasons 2006/07 y 2007/08. RYT in 2006/7 was higher than one in all treatments while in 2007/8 in any treatment exceeded one. Possible causes of that are attributed to differences in the amount and distribution of rainfall between seasons. Thus, weather forecasts could be used to determine the chances of success of the soybean-corn intercropping. Soybean-corn intercrop may be a promising alternative in view of the sustainability of soil resources to have positive values of carbon balance mainly when corn density in intercrops is medium to high.
\end{abstract}

Keywords: intercropping, soybean, corn, carbon balance.

\section{Introduction}

The area planted with soybean in Argentina has increased steadily in recent years along with the reduction of the area sown with cereals such as corn or sorghum. This affected negatively the soil quality [5] due to the small contribution of stubble and its high rate of decomposition, resulting in a negative carbon balance and decrease in organic matter content of the soil [16].

A possible alternative to plant soybeans and decrease the negative effects of this on soil quality could be planting soybeans in intercrop with corn.

In terms of land use, intercrops are considered more productive than their pure cultures $[11,8]$ due to the complementary use of environmental resources [19]. Production efficiency, in intercropping systems, can be improved by minimizing the interspecific competition between the component crops by limiting growth factors [19]. Competition can be regulated, among others management factors, by the density of components crops $[17$, 8].

The productivity of soybean-corn intercropping generally is higher than its pure cultures, which is reflected in productivity index as the Relative Yield Total (RYT) of 1.31 to 1.49 [2], 1.11 to 1.15 [6], 1.09 to 1.11 [20], 1.18 [18], 1.1 to 1.22 [1], 1.3 to 1.45 [13]. However in some situations have been reported RYT less than one $[6,18]$.

Higher productivity of this intercrop system is achieved by a soybean lower productivity, whereas the corn productivity is unchanged or even increased [10]. In this regard, the sowing of twenty soybean genotypes between corn rows produced a soybean yield between 17 to $42 \%$ of the pure culture, while corn yield was between $81-108 \%$ relative to the pure culture [14].
The objective of this work was to evaluate the effect of corn density on grain yield, dry matter productivity and carbon balance of soybean - corn intercropping system.

\section{Materials and methods}

The study were carried out in the experimental area of Faculty of Agricultural Sciences of the National University of Cordoba, Argentina ( $31^{\circ} 28^{\prime} 42.57^{\prime \prime S}$ and $\left.64^{\circ} 00^{\prime} 27.50^{\prime \prime} \mathrm{W}\right)$. The treatments were pure stand of soybean (PS), pure stand of corn (PC) and four intercrops varying in corn densities: 1, 2, 4 and 8 plants* ${ }^{-2}$ (named SCI1, SCI2, SCI4 and SCI8, respectively). The array of rows was one row of soybean one row of corn, with a row distance of $0.52 \mathrm{~m}$. The first experiment was sown on December 20, 2006 while the second was sown on December 27, 2007. In the last all treatments were evaluated except SCI1. Soybean density was 40 plants* $\mathrm{m}^{-2}$. The plots were constituted by five rows in the case of PC and PS treatments and six-rows on intercropping treatments.

Soybean cultivar was SPS 4500 and corn hybrids were SPS 2722RR in first experiment and DK864RR in the second. The biological adversities were controlled chemically and weed control was complemented manually. Crop phenology was followed on the basis of appropriate scales $[7,15]$.

At physiological maturity of both crops whole plants on a surface of $4 \mathrm{~m}^{2}$ were harvested manually. Samples were placed into drying chamber at $60{ }^{\circ} \mathrm{C}$ to constant weight. Total dry matter (TDM) and grain yield (GY), were obtained.

To evaluate the grain and dry matter productivity of each intercrop treatment, RYT [11] was calculated as the sum of the relative yields (RY) of each component crop of the intercrop according to the following: 


\section{International Journal of Science and Research (IJSR) \\ ISSN (Online): 2319-7064 \\ Index Copernicus Value (2013): 6.14 | Impact Factor (2013): 4.438}

$\mathrm{RYT}=\mathrm{RYc}+\mathrm{RYs}$

$\mathrm{RYc}=\mathrm{Yc}, \mathrm{s} / \mathrm{Yc}$

$\mathrm{RYs}=\mathrm{Ys}, \mathrm{c} / \mathrm{Ys}$

where: RYc is the relative yield of corn, RYs is the relative yield of soybeans, $\mathrm{Yc}, \mathrm{s}$ is the corn yield in intercropping with soybean, Yc corn yield in pure stand, Ys, $\mathrm{c}$ is the soybean yield in intercropping with corn and Ys is the yield of soybean in pure stand.

Carbon balance (CB) was estimated by the following methodology [3]:

$\mathrm{CB}=\mathrm{CPC}-\mathrm{CL}$

where:

CPC: carbon provided by the crop to the soil

CL: carbon lost from de soil

CPC was calculates considering that $40 \%$ of the aerial vegetative dry matter plus the contribution made by the roots ( $20 \%$ of the aerial vegetative dry matter) was $\mathrm{C}$ and the $50 \%$ of this $\mathrm{C}$ becomes humified organic matter:

$\mathrm{CPC}=(\mathrm{AVDM}+\mathrm{RDM}) * 0.4 * \mathrm{Hc}$

where: AVDM: aerial vegetative dry matter

RDM: roots dry matter $=\mathrm{AVDM} * 0.2$

Hc: humification coefficient $=0.5$
CL was calculated based on the $\mathrm{C}$ mass in the top $20 \mathrm{~cm}$ of soil affected by the mineralization rate typical for our environmental conditions:

$\mathrm{CL}=\mathrm{MCs} * \mathrm{MR}$

where:

MCs: Mass of carbon in the soil ( 0 to $0.20 \mathrm{~m}$ layer)

MR: mineralization rate $=0.0535$

Climate data were obtained from agrometeorological station located near experiments. Data was analyzed as completely randomized block design with three replications. ANOVA and multiple comparisons test were performed using Infostat software [4].

\section{Results and Discussion}

The dry matter production of soybean was affected by competition of corn with the exception of SCI1 treatment in 2006/7 (Table 1). The negative effect on dry matter production of soybeans was higher as plant density of corn increased. The dry matter production of corn increased with its density being the highest values in PC, SCI8 and SCI4 treatments in 2006/7 and PC treatment in 2007/8. The higher total dry matter (soybean plus corn dry matter) were obtained in PC, SCI4 and SCI8 treatments (2006/7) and in PC treatment (2007/8).

Table $\mathbf{N}^{\circ}$ 1: TDM, GY, RY and CB in the intercrops and pure stand treatments

\begin{tabular}{|c|c|c|c|c|c|c|c|c|c|}
\hline \multirow{2}{*}{ Variable } & \multirow{2}{*}{ Season } & & \multicolumn{6}{|c|}{ Treatments } & \multirow{2}{*}{$L S D$} \\
\hline & & & PS & PC & ISC1 & ISC2 & ISC4 & ISC8 & \\
\hline \multirow{6}{*}{$\begin{array}{c}\text { TDM } \\
\left(\mathrm{g}^{*} \mathrm{~m}^{-2}\right)\end{array}$} & \multirow{3}{*}{$2006 / 7$} & Soybean & 827 & & 643 & 446 & 323 & 237 & 191 \\
\hline & & Corn & & 2094 & 674 & 1060 & 1673 & 1984 & 359 \\
\hline & & Total & 827 & 2094 & 1317 & 1506 & 1996 & 2220 & 320 \\
\hline & \multirow{3}{*}{$2007 / 8$} & Soybean & 603 & & & 243 & 157 & 67 & 45 \\
\hline & & Corn & & 2927 & & 1118 & 1845 & 2263 & 555 \\
\hline & & Total & 603 & 2927 & & 1361 & 2002 & 2330 & 559 \\
\hline \multirow{6}{*}{$\begin{array}{c}\mathrm{GY} \\
\left(\mathrm{g}^{*} \mathrm{~m}^{-2}\right)\end{array}$} & \multirow{3}{*}{$2006 / 7$} & Soybean & 338.2 & & 258.8 & 172.7 & 106.3 & 66 & 54 \\
\hline & & Corn & & 920.4 & 327.4 & 509.2 & 824.4 & 905.6 & 168 \\
\hline & & Total & 338.2 & 920.4 & 586.2 & 681.9 & 930.7 & 971.6 & 133 \\
\hline & \multirow{3}{*}{$2007 / 8$} & \begin{tabular}{|l|} 
Soybean \\
\end{tabular} & 333 & & & 130.1 & 73 & 31.4 & 11.8 \\
\hline & & Corn & & 1110 & & 380.7 & 709.1 & 1004 & 256 \\
\hline & & Total & 333 & 1110 & & 510.9 & 782.1 & 1035 & 252 \\
\hline \multirow{6}{*}{ RY } & \multirow{3}{*}{$2006 / 7$} & Soybean & & & 0.77 & 0.51 & 0.31 & 0.2 & 0.11 \\
\hline & & Corn & & & 0.36 & 0.55 & 0.9 & 0.98 & 0.20 \\
\hline & & Total & & & 1.12 & 1.07 & 1.21 & 1.18 & 0.14 \\
\hline & \multirow{3}{*}{$2007 / 8$} & Soybean & & & & 0.39 & 0.22 & 0.09 & 0.04 \\
\hline & & Corn & & & & 0.34 & 0.64 & 0.9 & 0.13 \\
\hline & & Total & & & & 0.73 & 0.86 & 1 & 0.10 \\
\hline \multirow{2}{*}{$\begin{array}{c}\mathrm{CB} \\
\left(\mathrm{kg} \mathrm{C}^{*} \mathrm{ha}^{-1}\right)\end{array}$} & $2006 / 7$ & & -1522.8 & 121.0 & -942.2 & -717.5 & -140.1 & 300.9 & 484.0 \\
\hline & $2007 / 8$ & & -2048.8 & 1664.0 & & -656.5 & 232.5 & 411.1 & 745.1 \\
\hline
\end{tabular}

LSD: least significant difference

The soybean yield in the PS treatment was similar in both seasons, while the corn yield in PC treatment was slightly higher in 2007/8 than in 2006/7 (Table 1). Grain yield of soybean in intercropping was significantly affected by the presence of corn and this effect was greater as corn density increased. Corn yield was lower as its density was reduced. The highest intercrop grain yields were obtained with PC, SCI8 and SCI4 treatments in 2006/7 and with PC and SCI8 treatment in 2007/8.
The RY of soybean decreased with increasing density of corn in both seasons being greater this effect in 2007/8. The RY of corn increased with its density being close to one in SCI8 and SCI4 treatments in 2006/7, and in SCI8 in 2007/8. RYT in 2006/7 was higher than one in all treatments, reaching 1.21 in the SCI4 treatment although with no significant differences with SCI1 and SCI8. In 2007/8 the RYT in any treatment exceeded one.

Promising productivity rates of intercropping in 2006/7 not repeated in 2007/8. This may be due to different 


\section{International Journal of Science and Research (IJSR) \\ ISSN (Online): 2319-7064 \\ Index Copernicus Value (2013): 6.14 | Impact Factor (2013): 4.438}

environmental conditions between seasons, especially the amount and distribution of rainfall. The sum of those occurring in December, January and February were similar in both seasons (328 and $299 \mathrm{~mm}$ in $06 / 07$ and 07/08, respectively), while those occurring during March and April were different (287 and $42 \mathrm{~mm}$ in $06 / 07$ and $07 / 08$, respectively). The shortage of water during the reproductive stage of crops in 2007/8 could have affected mainly dominated crop (soybean) and to a lesser extent dominant crop (corn). It has been reported that given a reduction in water availability, corn in intercropping with soybeans decreased productivity in lesser extent than corn in pure stand, while intercropped soybean decreased its productivity higher than pure soybean [12]. They attributed this behavior to that corn intercropped with soybean is favored by a greater availability of resources, which favors not only aerial but their root growth and thus achieved a greater capacity to explore resources such as water and nutrients. The opposite occurs with soybeans, therefore water shortages significantly reduces its productivity in association with corn. Under stress conditions, intercropping yields could well be less than sole crop yields because of increased competition for moisture [9].

CB was positive in SCI8 and PC treatments in 06/07 season, while in 07/08 season was positive in PC, SCI8 and SCI4. The other treatments showed negative values of $\mathrm{CB}$, highlighting PS with the most pronounced negative value (Table 1).

The results are inconclusive about the productivity of soybean-corn intercropping systems in relation to pure crops. While in one season the productivity was higher in intercropping, on the other, no intercropping achieved RYT greater than one. Possible causes are attributed to differences in amount and distribution of rainfall. Considering that, the use of weather forecasts can be used to determine the chances of success of the soybean-corn intercropping.

Soybean-corn intercrop may be a promising alternative in view of the sustainability of soil resources to have positive values of BC mainly when corn density is medium to high.

\section{References}

[1] J.R. Allen and R. Obura, "Yield of corn, cowpea and soybean under different intercropping systems". Agronomy Journal 75, pp. 1005-1009, 1983.

[2] D.A. Alvarenga, P.M. de Rezende, M.J.B. de Andrade, L.A. de Bastos Andrade, "Consorcio soja-milho; 5: efeito de sistemas de consorcio e de semeadura do milho". Ciencia Rural 28 (2), pp. 199-204, 1998.

[3] R. Alvarez, "Balance de Carbono en los suelos". INTA Estación Experimental Agropecuaria Rafaela. Información Técnica de Trigo, Publicación Miscelanea $\mathrm{N}^{\mathrm{o}} 105,2006$.

[4] J.A. Di Rienzo, F.Casanoves, M.G. Balzarini, L. Gonzalez, M. Tablada, C.W. Robledo, "InfoStat versión 2011”. Grupo InfoStat, FCA, UNC, Argentina. Available: http://www.infostat.com.ar, [Accessed: Oct. $12,2015]$
[5] G.F. Domínguez and G.A. Studdert, "Balance de carbono en un molisol bajo labranza convencional". XX Congreso Argentino de la Ciencia del Suelo, 2006.

[6] L.A. Echarte and A. Della Maggiora, "Respuesta de la intersiembra maíz-soja a la densidad de plantas de maíz". Workshop Internacional: "Eco Fisiología Vegetal Aplicada al Estudio de la Determinación del Rendimiento y la Calidad de los Cultivos de Granos". Primer Encuentro Red Raíces de Ecofisiología SECyT. 6-7 septiembre 2007. Mar de Plata, Argentina.

[7] W.R. Fehr and C.E. Caviness, "Stages of soybean development". Cooperative Extension Service. Iowa State University. Ames Iowa 50011. Special Report 80. $11 \mathrm{p}, 1981$.

[8] S. Fukai, and B.R.Trenbath, "Proceses determining intercrop productivity and yields of component crops", Field Crops Research 34, pp. 247-271, 1993.

[9] M. Natarajan, R.W. Willey, "The effects of water stress on yield advantages of intercropping systems". Field Crops Res. Volume 13, pp. 117-131, 1986.

[10] J.C.W. Odongo, D.S.Veresoglou, D. Papakosta, A.G. Sficas, "Effects of population density, nitrogen fertilization and inoculation on the yields of intercropped corn and soyabeans in Greece", Journal Agricoltura Mediterranea 120 (1), pp. 3-12, 1990.

[11] F. Ofori and R.W. Stern, "Cereal-Legume Intercropping Systems". Adv.in Agronomy 41, pp. 41-90, 1987.

[12] S.A. Ouda, T. El Mesiry, E.F. Abdallah and M.S. Gaballah, "Effect of Water Stress on the yield of Soybean and Corn Grown under Different Intercropping Patterns". Australian Journal of Basic and Applied Sciences, 1(4), pp. 578-585, 2007.

[13] R.B. Prasad and R.M. Brook, "Effect of varying corn densities on intercropped corn and soybean in Nepal", Exp.Agric. 41, pp. 365-382, 2005.

[14] P.M. de Rezende, M.J.B. de Andrade, L.A. de B. Andrade,"Consorcio soja-milho II. Seleção de materiais genéticos de soja para consórcio com milho". Ciência e Prática 16 (3), 1992.

[15] S. Ritchie and J. J. Hanway, "How a corn plant develops". Iowa State Univ. of Science and Technology, Coop. Ext. Service, pp. 48, 1982.

[16] G. Studdert and H. Echeverría, "Crop rotations and nitrogen fertilization to manage soil organic carbon dynamics". Soil Sci. Soc. Am. J. 64, pp. 1496-1503, 2000.

[17] B.R. Trenbath, "Plant interactions in mixed crop communities", in Multiple Cropping, R.I.Papendick, P.A.Sanchez and G.B.Triplett (eds.), Madison, Wiscosin, 1976.

[18] R.R. Weil and M.E. McFadden, "Fertility and Weed Stress Effects on Performance of Corn/Soybean Intercrop". Agronomy Journal 83 (4), pp. 717-721, 1991.

[19] R.W. Willey, "b. Intercropping-Its Importance and Research Needs. Part 2. Agronomy and Research Approaches”. Field Crop Abstr. 32, p. 73-85, 1979.

[20] J.L. Zamar and G. Giambastiani, "Cultivo intercalado maíz-soja. Un aporte a la sustentabilidad en la región semiárida argentina". Agriscientia 13, pp. 65-69, 1996. 